\title{
Dictynna
}

Dictynna

Revue de poétique latine

18 | 2021

Varia

\section{Exsequiis at Virgil Aeneid 7.5 and the Epitaph of Caieta (7.1-4)}

\section{Francis Cairns}

\section{Q OpenEdition \\ 1 Journals}

\section{Electronic version}

URL: https://journals.openedition.org/dictynna/2515

DOI: 10.4000/dictynna.2515

ISSN: 1765-3142

\section{Publisher}

Université de Lille

\section{Electronic reference}

Francis Cairns, "Exsequiis at Virgil Aeneid 7.5 and the Epitaph of Caieta (7.1-4)", Dictynna [Online], 18। 2021, Online since 01 December 2021, connection on 18 December 2021. URL: http:// journals.openedition.org/dictynna/2515 ; DOI: https://doi.org/10.4000/dictynna.2515

This text was automatically generated on 18 December 2021.

\section{(c) (i) () $९$}

Les contenus des la revue Dictynna sont mis à disposition selon les termes de la Licence Creative Commons Attribution - Pas d'Utilisation Commerciale - Pas de Modification 4.0 International. 


\title{
Exsequiis at Virgil Aeneid 7.5 and the Epitaph of Caieta (7.1-4)
}

\author{
Francis Cairns
}

tu quoque litoribus nostris, Aeneia nutrix, aeternam moriens famam, Caieta, dedisti; et nunc servat honos sedem tuus, ossaque nomen Hesperia in magna, si qua est ea gloria, signat. at pius exsequiis Aeneas rite solutis, 5 aggere composito tumuli, postquam alta quierunt aequora, tendit iter velis portumque relinquit. (Aeneid 7.1-7)

"You too, Caieta, nurse of Aeneas, in dying bestowed eternal fame on our shores, and even now your honour keeps its place, ${ }^{1}$ and (if this is any glory) your name marks your bones in the great Western Land. But dutiful Aeneas, after conducting your funeral with due ceremony, and heaping up your tomb-mound, when the seas had calmed, set sail on his course and left the port. »

1 Exsequiis at Aeneid 7.5 has received its share of scholarly attention. Nicholas Horsfall opined that this was not the first appearance of exsequiae in epic/tragedy: "Unlikely that the noun (of notably convenient shape) was really introduced to high poetry as late as V." ${ }^{2}$ More recently exsequiis has been emended out of the Virgilian lexicon. ${ }^{3}$ The present paper proposes that the presence of exsequiis in the Aeneid can be explained and justified by the role of exsequiae in Roman elegy, and by the proximity of exsequiis to the epitaph of Caieta (Aeneid 7.1-4). Moreover, the history of exsequiae in elegy, once reconstructed, reveals both a hitherto unrecognised influence upon Virgil at this point in the epic, and a new possible implication of Caieta's death and memorialising.

\section{Exsequiae and its Gallan origin}

2 Exsequiis is the right word at the right place in the Aeneid. When Virgil was composing the Aeneid, ex(s)equiae in Latin poetry was primarily an elegiac term. In contrast to its virtual absence from the Aeneid, it is found fairly frequently (16 times) in the elegies of 
Tibullus, Propertius and Ovid, mostly (11 times) in pentameters. The statistics are: Tibullus 1 [in a pentameter]; Propertius 6 [4 in pentameters, 2 in hexameters]; Ovid $^{4} 9$ [6 in pentameters, 3 in hexameters]. ${ }^{5}$ As an elegiac term exsequiae matches Aeneid 7.5's context (see \$II), and its occurrences reveal its history within Roman elegy, which in turn illuminates the first lines of Aeneid 7. Four of the 11 pentameters from elegy which contain forms of exsequiae place them at their line-ends, thus creating polysyllabic pentameter endings:

nec qui det maestas munus in exsequias (Tibullus 2.4.44)

hic timor est ipsis durior exsequiis (Propertius 1.19.4)

plebei parvae funeris exsequiae (Propertius 2.13.24)

Dareique docent funeris exsequiae (Ovid Tristia 3.5.40)

In the past the standard view of such endings was that they are characteristic of earliness, and that, as time went on, they fell more and more out of favour. ${ }^{6}$ More recently I have argued that in early imperial elegy they are a sign of the influence of Cornelius Gallus upon his elegiac successors. ${ }^{7}$ exsequiae is a particularly plausible example of a term which can be identified as Gallan: it has no Catullan antecedent, and its use by all three Augustan elegiac successors of Gallus in polysyllabic pentameter endings is telling. Equally telling is the lack of any overlaps of content or context between the four examples, and likewise their employment of three different cases of exsequiae. Both factors suggest that imitation of any one of the three extant elegiac poets by another must be ruled out: that leaves Gallus as the source for all three. Again, while Propertius has many polysyllabic pentameter endings - a sign of the heavy influence on him of Gallus - Tibullus has notably fewer of them; this is in keeping with the relatively low amount of Gallan influence generally detectable in Tibullus, which gives greater prominence to those polysyllabic pentameter endings which he did employ. Ovid avoided polysyllabic pentameter endings completely in his earlier works; they appear only in the late works of his exile, ${ }^{8}$ when Ovid seems to have been reflecting on the parallel between his own fall from imperial grace and Gallus' fallingout with Augustus.

4 The notion that the elegiac use of exsequiae is Gallan in origin is further strengthened by the independently attested Gallan terms (emboldened) ${ }^{9}$ which accompany exsequiae in six pentameters of his successor elegists (including two of the line-end examples quoted above). Not all are equally impressive, but among them nomen is especially convincing since it is at the core of a group of related terms - nomen, notus, (and ignotus), nota, nescio and nobilis - which are especially diagnostic of Gallus. ${ }^{10}$

carmina: nuper ab exsequiis carmina rapta meis (Ovid Tristia 1.1.118, cf. 3.14.20)

durus: hic timor ${ }^{11}$ est ipsis durior exsequiis (Propertius 1.19.4)

durus: dure, neque exsequias prosequerere meas (Ovid Tristia 1.8.14)

munus: nec qui det maestas munus in exsequias (Tibullus 2.4.44)

nomen: maius ab exsequiis nomen in ora ${ }^{12}$ venit (Propertius 3.1.24)

nomen: nomen, ab exsequiis quod dare fama ${ }^{13}$ solet (Ovid Tristia 4.10.122)

The SPTAE Gallan Index contains around 400 entries, a small but significant proportion of which are concepts, not Latin words. The fact that 6 of the 11 occurrences of exsequiae in Augustan elegy can readily be matched with items from the Index is an encouraging result. Gallan elegy as a whole must have had a larger vocabulary.

Even if the conclusion that exsequiae appeared in the works of Gallus seems plausible, there can still be no certainty about the phrase or phrases in which it was embedded; but a fair conjecture might identify one of them as funeris exsequiae, which is found as 
the second hemistich of a pentameter at both Propertius 2.13.24 and Ovid Tristia 3.5.40 (above). ${ }^{14}$ The Consolatio ad Liviam provides further support; its author knew the works of Gallus, ${ }^{15}$ and he used this phrase in two pentameters, albeit in two different sedes:

funeris exsequiis adsumus omnis eques (202)

et sensi exsequias funeris ipse mei (460)

7 Neither of these lines looks to be derived from either of the comparable lines, viz.: Propertius 2.13.24 and Ovid Tristia 3.5.40 (both cited above); hence Gallus is the most likely source. Gallus may also have used exsequiae in the phrase ab exsequiis (cf. Propertius 3.1.24; 4.7.5 and Ovid Tristia 1.1.118).

\section{Caieta's 'Gallan' epitaph}

8 The four lines (quoted ad init.) which precede Aeneid 7.5 and begin Book 7 are in effect the epitaph of Aeneas' old nurse Caieta; the pietas which line 5's pius ... Aeneas attributes to him refers to his burial of Caieta and his implied epitaphic memorialising of her as a due return for her rearing of him. Hellenistic epigrams, both literary and epigraphic, survive which show other 'pious' nurslings performing the same service for other deceased nurses. ${ }^{16}$ Elegiac exsequiae at Aeneid 7.5 almost foot-notes the preceding four lines, which Virgil of necessity composed as hexameters, by characterising them as in spirit an elegiac funerary 'epigram'; in Virgil's day a funerary epigram on a tombstone

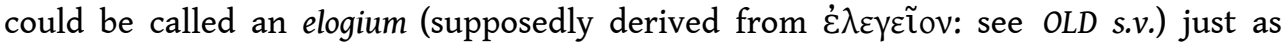
readily as an epigramma. All this would have been readily understood by Virgil's contemporaries: one of elegy's two primary functions was to lament and celebrate the dead, and elegiac couplets were for them the metre in which most epitaphs were composed. Line 5 would have been seen even more clearly as a genuflection to the canonical metre of epitaphs if the close association of exsequiae with Gallus, the pioneer of Roman elegy, proposed above is correct.

The Gallan ethos conveyed by exsequiis is even more extensive, if, as seems to be the case, the standard vocabulary of elegiac epitaphs long recognised in lines $1-4^{17}$ is supplemented by a Gallan colour. Given that very few lexemes are directly attested as Gallan, and that the number of those which (without reference to Aeneid 7.1-4) have been additionally advanced as plausibly Gallan is also limited, it is fairly striking that in these four lines five ${ }^{18}$ such lexemes surface, viz.:

1. litoribus (1) appears in the exact form independently identified as Gallan. ${ }^{19}$

2. nomen (3) is one of the most iconic Gallan terms (SPTAE Gallan Index s.v.).

3. Hesperia (4) is linked to Gallus' boasts of his world-wide reputation (SPTAE Gallan Index s.v.)

4. ossa (3) is found in combination with Gallan molliter ${ }^{20}$ at Eclogue 10.33: o mihi tum quam molliter ossa quiescant. These words are placed by Virgil in the mouth of his character 'Gallus', and they must reflect what Gallus himself had uttered (or what someone else had wished for him) in his own poetry. Ovid uses the phrase molliter ossa cubent as the second hemistich of three pentameters (Amores 1.8.108; Heroides 7.162; ${ }^{21}$ Tristia 3.3.76); in the third of these (dicere Nasonis molliter ossa cubent) he is anticipating his own death, perhaps using the same formula as Gallus had used of his own decease.

5. famam (2) has a good claim to be Gallan: it rests on the close associations of fama with a number of other terms of certain or plausible Gallan pedigree. I begin with the Propertian examples. ${ }^{22}$ 
a) Famam, Roma, tuae non pudet historiae (3.22.20)

This line links fama to that certain and influential Gallan term historia (cf. Gallus fr. 2.3 Courtney); for non pudet with fama cf. occidit, Argivae fama pudicitiae, 1.15.22.

b) fallere te numquam, Galle, puella velit

dum tibi deceptis augetur fama puellis (1.13.4-5)

Here Gallus himself appears. ${ }^{23}$

c) hic mihi conteritur vitae modus, haec mea famast, hinc cupio nomen carminis ire mei (1.7.9-10)

mendax fama, vaces: alius mihi nominis index (4.2.19)

These two Propertian loci unite fama with the key Gallan term nomen. ${ }^{24}$ To counter the potential objection that fama and nomen are (near-)synonyms, and sit together for that reason, Ovid Tristia 5.12.39: nominis et famae quondam fulgore trahebar may be cited. Shortly before this juxtaposition Ovid makes his intent to allude to Gallus clear by reproducing with witty variations a signature Gallan phrase:

carmina nulla mihi veniunt aut qualia cernis, digna sui domini tempore, digna loco (Ovid Tristia 5.12.35-36)

Cf. ] .... tandem fecerunt c[ar]mina Musae quae possem domina deicere digna mea. (Gallus fr. 2.6-7 Courtney).

Here Ovid is insisting that he, not the Muses, is the author of his own verses by replacing Gallus' domina with himself as (their) dominus.

Supplementary evidence that fama is Gallan comes from associations in the elegies of Propertius between it and other terms plausibly linked to Gallus: there are two linkages (3.9.33-34; 4.11.29) between fama and tropaea within a line or couplet, and there are single Propertian instances where fama is juxtaposed with other independently identified Gallan terms: with luxuria (1.16.11-12, cf. also infamis (9) and nobilis (10)); with principiis (2.6.15-16); with labores (2.23.7); and with maxima (4.2.42). These Propertian loci are only a selection: more could have been added, and yet more from Ovid; the Ovidian material often confirms the conclusions drawn from the Propertian examples.

Caieta's 'funeral epigram' now emerges as studded with (the emboldened) Gallan terms:

tu quoque litoribus nostris, Aeneia nutrix,

aeternam moriens famam, Caieta, dedisti;

et nunc servat honos sedem tuus, ossaque nomen

Hesperia in magna, si qua est ea gloria, signat. (Aeneid 7. 1-4)

\section{A Possible Implication}

13 Virgil was at work on the Aeneid in the 20s BC. Exactly when this particular portion of the epic was composed is unknown; but during that decade Gallus would still have been, in the minds of his contemporaries, the elegist par excellence; and Propertius and Ovid, and even to some extent Tibullus, would have been seen as his followers. Virgil was supremely conscious of the sources on which he drew, and he had enjoyed close personal contact with Gallus in the forties and thirties BC. Even if the assertion of Probus $^{25}$ that they had been fellow-pupils has no historical value, it is at least certain that Gallus was one of Virgil's two major patrons in the Eclogues, the other being Asinius Pollio. Eclogues 6 and 10 show that Virgil had a thorough knowledge of Gallus' works, and the two poems, especially 10, conduct, on behalf of hexameter bucolic, a literary 'polemic' with Gallan elegy. Although Virgil had moved into the patronage of 
Maecenas by 37 BC, he will not have forgotten Gallus as one of his former patrons, any more than Propertius forgot Gallus as both his former patron and his literary model (2.34.91-92); even Ovid, who as far as we know had no personal contact with Gallus, ${ }^{26}$ was unable to forget him as his model in elegy and (involuntarily) in life. The fall and suicide of Gallus must therefore have affected Virgil, as it did Propertius and Ovid.

Martin Dinter, expanding on the work of predecessors, has several times discussed the epigraphic and epitaphic aspects of Aeneid 7.1-4, ${ }^{27}$ and how they might guide our understanding of them. Those of his observations which are relevant to this paper can be summarised most economically by selective quotation from his earliest contribution (of 2005):

"Caieta marks several transitions: the reader crosses a poetic border, a book division. But he progresses not only from one book roll to the next but also from the Odyssean half of the Aeneid (1-6) to the Iliadic (7-12)" (159).

"Caieta's epigram forms part of an implicit programmatic discussion in the Aeneid: the four lines are marked out through their position, the presence of the poet's person (at 7.5 distinguishes him from Aeneas), and the opening phrase tu quoque. Finally Caieta's death demonstrates that Aeneas has truly grown up ... The alien coast has become litoribus nostris, a homeland (Italia nutrix). Aeneas ... has 'come home'; he will need his nurse no more ... Virgil stresses that the Trojans' arrival in Italy actually means a coming home. The epigrams are part of the undoing of Trojanness ..." (160).

These observations help to tease out a possible implication of the Gallan colour of Caieta's epitaph. The episode of Caieta's death and burial has long been seen as a transitional moment in Aeneas' journey from Troy to Italy; as Dinter noted, Caieta's epitaph is thus liminal, standing as it does at the centre point of the Aeneid, and marking the move from Odyssey to Iliad as the epic's primary model, ${ }^{28}$ and from Troy to Italy as Aeneas' patria. The epitaph could also be seen as reflecting Virgil's own literary journey: Dinter's remark about the presence of "the poet's person" in 7.5 (above) points the way here. Virgil, like some other Roman poets, ${ }^{29}$ was interested in the ongoing phases of his own career. ${ }^{30}$ I suggest that he may have been analogising himself in Aeneid 7.1-7 with Aeneas, and recalling his former association with Gallus, and his own literary progression from that point on. It started with the Eclogues - composed in part under the patronage of Gallus, and adhering to a literary type with many overlaps with Gallan elegy ${ }^{31}$ - and it moved on first to the intermediate Georgics (dedicated to Maecenas, but possibly initially intended also for Gallus?), and finally to his Aeneid commissioned by Augustus and in progress. Whether a patron could be called a nutrix in Latin is unclear. Domitius Marsus (fr. 3 Courtney; fr. 176 Hollis) described Caecilius Epirota as tenellorum nutricula vatum, either as a teacher or commentator ${ }^{32}$ or both, but not as a patron ${ }^{33}$ Nevertheless, the term nutrix is at least suggestive: might one aspect ${ }^{34}$ of Caieta's Gallan epitaph be that in it Virgil, as Gallus' 'pius' alumnus, was paying a quiet implied tribute to his dead former patron ${ }^{35}$ now that he had reached his true home in the ongoing Aeneid.

\section{Conclusions}

16 I hope to have shown in \$I that exsequiis is at home in Aeneid 7.5 as an elegiac and Gallan term which footnotes the elegiac ethos and content of Caieta's preceding epitaph (1-4). In SII I have argued that Caieta's epitaph too is linguistically Gallan, which makes 
exsequiis doubly in place. Finally, in \$III I have suggested, as an explanation of the Gallan language of Aeneid 7.1-5, that there is perhaps an additional, hitherto unobserved, element of liminality in Caieta's epigram: that Virgil saw Aeneas' move from Troy to Italy as analogous to his own literary move from the Gallan, and Gallussponsored, Eclogues via the Georgics to his own final destination, the Aeneid, sponsored by Augustus. Caieta's epitaph will thus also have functioned as a discreet tribute to Virgil's former patron, Cornelius Gallus.

\section{BIBLIOGRAPHY}

Barchiesi, A., 1979. 'Palinuro e Caieta. Due <<epigrammi>> virgiliani (Aen. V 870 sg.; VII 1-4)', Maia n.s. $1.3-11$

Cairns, F., 1989. Virgil's Augustan Epic. Cambridge

Courtney, E., 1993. The Fragmentary Latin Poets. Oxford

Dinter, M., 2005. 'Epic and epigram: minor heroes in Virgil's Aeneid', CQ 55.153-169

Dinter, M., 2011. 'Inscriptional intermediality in Latin elegy' in A.M. Keith (ed.) Latin elegy and Hellenistic epigram: a tale of two genres at Rome. Newcastle, 7-18

Dinter, M., 2013. 'Inscriptional intermediality in Latin literature' in P. Liddel, and P. Low, (edd.) Inscriptions and their uses in Greek and Latin literature. Oxford-New York, 303-316

Fabre-Serris, J., 2017. 'Sulpicia, Gallus et les élégiaques. Propositions de lecture de l'épigramme 3.13', EuGeStA 7.115-139

Gervais, K., 2019-2020. 'Positioning Aeneas: A Proposed Emendation to Aeneid 7.5', CJ 115.146-173

Hollis, A.S., 2007. Fragments of Roman Poetry c.60 B C-A D 20: Edited with an Introduction, Translation, and Commentary. Oxford

Horsfall, N., 2000. Virgil, Aeneid 7: A Commentary. Leiden-Boston-Köln

Kaster, R.A., 1995. Suetonius. De Grammaticis et Rhetoribus. Oxford

Kayachev, B., 2013. 'The ideal biography of a Roman poet: from lusus poetici to studia philosophica', Latomus 72.412-425

Knox, P.E., 1995. Ovid. Heroides, Select Epistles. Cambridge

Seider, A.A., 2012. 'Competing Commemorations: Apostrophes of the Dead in the Aeneid', AJP $133.241-269$

Skempis, M., 2010. 'Caieta's Undying Fame: Aeneid 7.1-7', MH 67.114-126

SPTAE = Cairns, F., 2006. Sextus Propertius: The Augustan Elegist. Cambridge 


\section{NOTES}

1. I take this cryptic clause (on which see Horsfall (2000) 48) to mean that the honour given to Caieta (i.e. the naming of the port after her) persists to this day, since the place is still called 'Caieta'. The logic of lines 1-4, then, will be that Caieta gave the shores eternal fame, and the port gave her the lasting honour of being named after her.

2. Horsfall (2000) 51.

3. Gervais (2019-2020), impugning it as "prosaic" and an "intrusive gloss" (150), and proposing that Virgil actually wrote at pius Aeneas sacris iam rite solutis (148), but also pointing out vulnerabilities in two of his most prominent arguments for this: the unusual separation of pius and Aeneas in Aen. 5.7 is paralleled at Aen. 5.418 (151); and the incorrect order Aeneas exequiis in some MSS is explicable as a "banalizing scribal error" (149).

4. There is one example in the Metamorphoses (ante urbem exequiae tumulique ignesque rogique, 13.687) - as a tribute to Virgil?

5. There are also 4 examples $(168,202,218,460)$, all in pentameters, in the elegiac Consolatio ad Liviam (almost certainly of later date).

6. See SPTAE 146 n.6.

7. SPTAE 146-183 = Ch.5 'Gallan Metrics I: Polysyllabic Pentameter Endings'.

8. For a list of them see SPTAE 181-182.

9. Their Gallan credentials can be accessed at SPTAE 483-487: 'II. Index of Gallan Words and Concepts' (henceforth abbreviated to 'SPTAE Gallan Index') s.vv.

10. SPTAE Gallan Index s.vv.

11. timor (Prop. 1.19.4) does not appear in SPTAE Gallan Index, but metuo and vereor do.

12. ora (shore) features in SPTAE Gallan Index, but not os (mouth).

13. fama is not listed in SPTAE Gallan Index, but arguments are advanced below (\$II) for its Gallan provenance; cf. also the thought-provoking exsequiae tantum famam nomenque volentem (Sil. Pun. 12.473).

14. The phrase appears at Digest 35.1.91pr (illa autem 'si ad exsequias funeris mei uenerit' nisi post mortem impleri non possit) in a discussion of conditions imposed (e.g.) by a testator; whether this gives it a legal flavour is unclear.

15. SPTAE 85-6, 415, 434-436, 439.

16. E.g. Callim. AP $7.458=49$ HE; Dioscor. AP $7.456=29$ HE; CEG nos 534; 571 .

17. For tu quoque (1), which is, if not exclusively, at least strongly evocative of epitymbic epigrams, see (e.g.) Barchiesi (1979) 10; Dinter (2011) 12-18; (2013) 308-314 (with earlier bibliography).

18. The last two (ossa and fama) are not included in the SPTAE Gallan Index, but are first argued for here.

19. SPTAE Gallan Index s.v. litus etc.; SPTAE esp. 154-155, 172-175, 200.

20. SPTAE Gallan Index s.v., and s.v. mollis.

21. Knox (1995) 228 recognised that Gallus was Ovid's source.

22. For evidence of the Gallan origin of the terms emboldened in the remainder of this section see SPTAE Gallan Index s.vv.

23. Add also the combined appearance of fama and pudor at Sulpicia [Tib.] 3.13.1-2, observed and discussed as Gallan by Fabre-Serris (2017).

24. A third (nec minus haec nostri notescet fama sepulcri, Prop. 2.13.37) involves a cognate.

25. Commentarius in Vergili Bucolica et Georgica 328.2 Hagen.

26. Hollis (2007) 309.

27. Dinter (2005) 159-160; (2011) 12-13; (2013) 308-310.

28. See, however, Cairns (1989) 177-214 = Ch. 8: 'The Aeneid as Odyssey', redefining the roles of the two Homeric epics in the Aeneid. 
29. E.g. Prop. 3.5.19-47; Hor. Epist. 1.1.1-11; Ov. Tr. 4.8.1-14; Ciris 1-9; cf. Philod. AP $11.41=17$ GPh.; AP 5.112 (= $18 \mathrm{GPh}$.).

30. Verg. Ecl. 6.1-8; Verg. Georg. 4.559-566; Kayachev (2013). Virgil's supposed epitaph (Mantua me genuit ... cecini pascua, rura, duces, VSD 36) and the false ille ego qui incipit of the Aeneid incorporate this theme retrospectively.

31. Hence the literary 'polemic' over bucolic and elegy between Virgil and Gallus in Ecl. 10, and between Propertius and Virgil at Prop. 2.34.67-76.

32. See Suet. De Gram. et Rhet. 16.3.

33. For various opinions on the fragment of Domitius Marsus, and on Caecilius Epirota, see Courtney (1993) 302; Kaster (1995) 188-190; Hollis (2007) 309.

34. For recent suggestions about further/alternative aspects see Skempis (2010) and Seider (2012).

35. Virgil's other major patron of the Eclogues, Asinius Pollio, was alive and flourishing at the time of Virgil's death.

\section{ABSTRACTS}

This paper argues that, contrary to what has recently been proposed, exsequiis is at home in Aeneid 7.5 as an elegiac and Gallan term which footnotes the elegiac ethos and Gallan language of Caieta's preceding epitaph (1-4). The paper also suggests that, in addition to its other recognised liminal aspects, the Gallan epitaph may show Virgil reflecting on his move from the Gallussponsored Eclogues via the Georgics to the Aeneid, sponsored by Augustus, and thus pay a discreet tribute to his former patron.

\section{INDEX}

Keywords: Virgil, Aeneid, Caieta, ex(s)equiae, Cornelius Gallus

\section{AUTHOR}

\section{FRANCIS CAIRNS}

Florida State University, Tallahassee

fcairns@fsu.edu 